\title{
EDUKASI POLA HIDUP SEHAT DAN PHYSICAL DISTANCING DI PEKON PATOMAN DAN PEKON PAGELARAN KECAMATAN PAGELARAN, PRINGSEWU
}

\author{
Dias Ardini, Pudji Rahayu, Siti Julaiha, Iwan Sariyanto, Nawasari Indah Putri, Musiana ${ }^{\text {* }}$ \\ Politeknik Kesehatan Tanjungkarang \\ Jl. Soekarno Hatta No. 1 Bandar Lampung \\ Penulis Korespodensi : musiana74@gmail.com
}

\begin{abstract}
Abstrak
Penyakit infeksi pernafasan akut yang disebabkan virus Corona telah dinyatakan WHO sebagai pandemi dunia. Wabah ini mengakibatkan lebih dari 53.900 kematian dan menyebabkan gangguan sosial ekonomi global. Sebagai wujud kepedulian terhadap situasi yang ada, dosen Poltekkes Tanjungkarang melakukan kegiatan pengabdian kepada masyarakat di pekon Patoman dan Pagelaran kabupaten Pringsewu sebagai desa mitra. Hasil penjajakan didapat penderita covid-19 sebanyak 1 orang, PDP 1 orang dan ODP sebanyak 23 orang. Tujuan kegiatan memberikan edukasi pola hidup sehat dan physical distancing sebagai upaya memutus rantai penyebaran covid-19. Bahan berupa kuesioner, media edukasi (leaflet dan poster) dan sarana pencegahan covid-19 seperti APD, masker, hand sanitizer, tempat cuci tangan dan sabun. Metode dengan pre test dan post tes, pemberian edukasi dan distribusi sarana pencegahan covid-19. Hasil pre test dan post test menunjukkan ada perbedaan pengetahuan masyarakat sebelum dan sesudah edukasi ( $p$ value 0,002). Materi edukasi sebanyak 500 eksemplar leaflet dan 400 eksemplar poster telah disampaikan kepada masyarakat termasuk distribusi tempat cuci tangan, hand sanitizer, sabun cuci tangan, desinfektan, dan pemberian alat pelindung diri seperti baju hazmat, masker medis, handscoen, kepada tenaga Kesehatan di Puskesmas Pagelaran dan satgas di Pekon Pagelaran, dan Pekon Patoman. Kesimpulan, kegiatan terlaksana dan dapat berjalan dengan baik serta hasilnya sesuai dengan indicator yaitu peningkatan pengetahuan masyarakat, masyarakat memanfaatkan masker, hand sanitizer dan tempat cuci tangan, dan hasil survey kepuasan masyarakat terhadap kegiatan baik. Saran, untuk terus memberikan edukasi tentang bahaya covid-19 dan upaya memutus rantai penyebaran dengan menerapkan protokol kesehatan yaitu pakai masker, cuci tangan dengan sabun, menjaga jarak dan menghindari kerumunan.
\end{abstract}

Kata kunci: Pencegahan, Covid-19, Physical Distancing, Edukasi

\section{Pendahuluan}

Penyakit infeksi corona virus yang berlangsung sejak akhir tahun 2019 merupakan wabah yang telah dilaporkan di lebih dari 180 negara dan 200 wilayah dan mengakibatkan lebih dari 206.997 kematian. Virus ini terutama menyebar melalui droplet yang dihasilkan ketika orang batuk, bersin, atau berbicara. Gejala utama Covid-19 yaitu demam, batuk kering, dispnea, fatigue, nyeri otot, dan sakit kepala. Selain gejala-gejala tersebut, dilaporkan pula gejala pada tractus gastrointestinal dan manifestasi neurologis (Fitriani, 2020).

Pandemi corona virus di Indonesia diawali dengan temuan penderita penyakit Covid-19 pada 2 Maret 2020. Hingga 22 Mei 2020, telah tekonfimasi 20.162 kasus positif Covid-19 dengan 14.046 kasus aktif, 4.838 kasus sembuh, dan 1.278 kasus meninggal. Angka covid di Lampung hingga 22 Mei 2020 terkonfirmasi 101 kasus positif, 6 meninggal, dan 31 sembuh. Pandemi Covid-19 menuntut kesiapan sistem pelayanan kesehatan dan keterlibatan masyarakat dalam memutus rantai penyebaran.

Upaya penurunan jumlah kasus memerlukan tindakan pencegahan yang tepat. Menurut WHO, pencegahan dapat dilakukan antara lain dengan mencuci tangan secara teratur, menghindari menyentuh bagian wajah, menjaga kebersihan, menutup mulut ketika batuk atau bersin, tetap berada di rumah bila merasa tidak sehat, dan menjaga jarak minimal satu meter. Kebijakan menjaga jarak (social distancing) diberlakukan di 
beberapa negara termasuk di Indonesia yang dikenal dengan istilah pembatasan social berskala besar, yang kini istilahnya menjadi physical distancing. Physical distancing merupakan upaya menjaga jarak antara satu orang dengan orang yang lain agar terhindar dari penularan penyakit COVID-19 dengan menghindari kerumunan ataupun keramaian (Syadidurrahmah et al., 2020). Pada kenyataannya masih banyak yang tidak menerapkan perilaku physical distancing ini dengan mengadakan pertemuan dan kegiatan yang melibatkan banyak orang. Selain physical distancing, pola hidup sehat juga tak kalah penting dalam upaya pencegahan penyakit ini mengingat bahwa penyakit ini disebabkan karena virus sehingga daya tahan tubuh berperan dalam mencegah masuknya virus kedalam tubuh.

Sebagai wujud kepedulian terhadap situasi yang ada, dosen Poltekkes Tanjungkarang yang berasal dari berbagai bidang keilmuan tergerak untuk melakukan kegiatan pengabdian kepada masyarakat melalui skema Program Pengembangan Desa Mitra (PPDM) di pekon Patoman dan Pagelaran kabupaten Pringsewu sebagai desa mitra. Hasil penjajakan didapat penderita covid-19 sebanyak 1 orang, PDP 1 orang dan ODP sebanyak 23 orang, belum tersedianya sarana cuci tangan di tempat umum, warga yang tidak menggunakan masker, dan keterbatasan alat pelindung diri bagi petugas.

Tujuan kegiatan memberikan edukasi pola hidup sehat dan physical distancing kepada masyarakat sebagai upaya memutus rantai penyebaran covid-19 sekaligus memberikan bantuan berupa alat pelindung diri dan sarana untuk pencegahan penularan covid-19.

\section{Bahan dan Metode}

Peralatan yang digunakan dalam kegiatan pengabdian masyarakat ini adalah kuesioner, media edukasi dan alat untuk pencegahan covid-19 seperti APD, masker, hand sanitizer, tempat cuci tangan, sabun.

Metode yang digunakan yaitu pemberian pre test dan post test, pemberian edukasi melalui media poster, pemberian APD, masker, hand sanitizer, tempat cuci tangan dan sabun Tahapan kegiatan dalam pelaksanaan program pengabdian kepada masyarakat ini meliputi :

1) Penjajakan, Pada tahap ini Tim Pengabdian kepada masyarakat melakukan survei dengan mengumpulkan informasi dari berbagai sumber (rekan sejawat yang bekerja di sarana pelayanan kesehatan dan dari masyarakat).

2) Sosialisasi dan Koordinasi, Pada tahap ini, Tim Pengabdian kepada masyarakat melakukan koordinasi dan sosialisasi terkait rencana kegiatan pengabdian masyarakat dengan aparat pemerintahan, masyarakat, dan petugas kesehatan di Pekon Patoman dan Pekon Pagelaran di Kabupaten Pringsewu Provinsi Lampung.

3) Pre test dan post test, Kegiatan pre test dan post test dilakukan menggunakan media online. Kuesioner berisi 24 pertanyaan terkait dengan covid-19 (pengetahuan covid-19, physical distancing, pencegahan penularan dan pola hidup sehat). Pre test dilakukan sebelum edukasi menggunakan media cetak, sedangkan post test dilaksanakan di akhir kegiatan pengabdian kepada masyarakat.

4) Edukasi, Penyebaran virus Covid-19 yang berlangsung secara masif, membutuhkan tindakan pencegahan secara berkesinambungan. Suatu upaya dalam rangka meningkatkan kesadaran masyarakat untuk memutus rantai penularan virus covid-19 yaitu melalui edukasi. Media yang disiapkan dalam proses edukasi pada kegiatan pengabdian masyarakat ini adalah media cetak berupa leaflet dan poster, selain itu tim juga mendemonstrasikan praktik cuci tangan dan cara menggunakan handsanitizer.

5) Distribusi sarana cuci tangan, masker, handsanitizer dan APD. Salah satu kegiatan penting dalam mengurangi risiko penularan Covid-19 yaitu sarana cuci tangan dan alat pelindung diri (APD). APD yang terdiri dari baju hazmat, masker bedah, dan sarung tangan didistribusikan ke Petugas kesehatan di Puskesmas Pagelaran. Distribusi tempat cuci tangan beserta sabun cuci tangan, masker dan handsanitizer kepada masyarakat melalui aparat pemerintahan desa mitra dan petugas kesehatan di Pekon Patoman dan Pekon Pagelaran di Kabupaten Pringsewu Provinsi Lampung. Pembuatan handsanitizer dilakukan di laboratorium oleh dosen-dosen di jurusan farmasi yang memiliki kompetensi di bidang tersebut dibantu oleh sejumlah mahasiswa. Handsanitizer dibuat berdasarkan formulasi standar dari WHO yang relative lebih mudah dan menggunakan 4 bahan saja yaitu Alkohol 96\%, Hidrogen peroksida, gliserol, dan aquadest. Handsanitizer yang diproduksi 
sebanyak 50 liter ini dikemas dalam botol spray 30 $\mathrm{ml}$, botol pump $250 \mathrm{ml}$ dan $500 \mathrm{ml}$.

6) Pemantauan Kegiatan, Pemantauan kegiatan dilakukan untuk memonitoring pengisian kuesioner, distribusi APD, masker, tempat cuci tangan, handsanitizer di Pekon Patoman dan Pekon Pagelaran serta menilai apakah sudah dimanfaatkan oleh petugas Kesehatan dan masyarakat. Pemantauan dilakukan melalui media komunikasi (telepon dan whatsapp). 7) Evaluasi, Evaluasi pelaksanaan Program melalui kuesioner kepuasan masyarakat di Pekon Patoman dan Pekon Pagelaran yang menjadi sasaran kegiatan pengabmas ini dengan indikator keberhasilan yaitu :

a) Peningkatan pengetahuan masyarakat yang ditandai dengan peningkatan skor post test

b) Bantuan masker, hand sanitizer, tempat cuci tangan terdistribusi ke masyarakat di Pekon Patoman dan Pekon Pagelaran.

c) Bantuan APD terdistribusi ke petugas kesehatan di Puskesmas yang ada di Pekon Patoman dan Pekon Pagelaran.

d) Masyarakat memanfaatkan masker, hand sanitizer dan tempat cuci tangan yang dibagikan

e) Hasil survei kepuasan masyarakat terhadap kegiatan yang dilakukan bernilai baik.

\section{Hasil dan Pembahasan}

Kegiatan pre test dilakukan dengan menyebarkan kuesioner melalui pejabat Pekon Patoman dan Pagelaran. Pre Test dan Post Test dilakukan pada penduduk Pekon Patoman dan Pekon Pagelaran sebanyak 40 orang. Hasil Pre test dan Post test dianalisis dengan menggunakan uji Wilcoxon. Hasil uji menunjukkan rata-rata persentase peningkatan pengetahuan 42,5\% (Patoman 30\% dan Pagelaran 55\%). Peningkatan pengetahuan masyarakat diperlukan untuk meningkatkan perilaku pencegahan covid-19. Hasil penelitian dengan judul Pengetahuan berhubungan dengan peningkatan perilaku pencegahan covid-19 di masyarakat diperoleh kesimpulan ada hubungan antara pengetahuan responden dengan perilaku pencegahan COVID-19 di masyarakat ( $\mathrm{p}$ value 0,001) (Mujiburrahman et al., 2020).

$$
\text { Media yang digunakan untuk }
$$
menyebarluaskan informasi sebagai bentuk edukasi terhadap masyarakat dalam rangka memutus rantai penyebaran covid-19 antara lain leaflet sebanyak 500 eksemplar dan poster sebanyak 400 eksemplar. Materi edukasi yang diberikan dalam bentuk leaflet berupa enam langkah cara mencuci tangan yang benar dengan menggunakan sabun. Adapun materi edukasi yang diberikan dalam bentuk poster antara lain materi tentang virus covid-19 dan strategi pencegahannya, hal-hal yang harus dilakukan saat isolasi mandiri, gerakan masyarakat dalam rangka menjaga diri dan keluarga dari Covid-19, dan pesan untuk petani dalam mencegah covid-19. Leaflet dan poster dibagikan ke Pekon Patoman dan Pekon pagelaran melalui kepala pekonn sambil memberikan informasi dan edukasi agar dapat disebarkan ke masyarakat setempat.

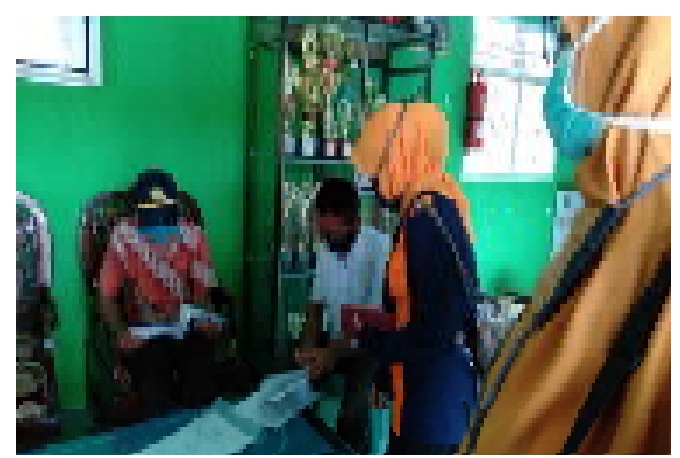

Gambar 1. Penjelasan Pre Test \& Post Test

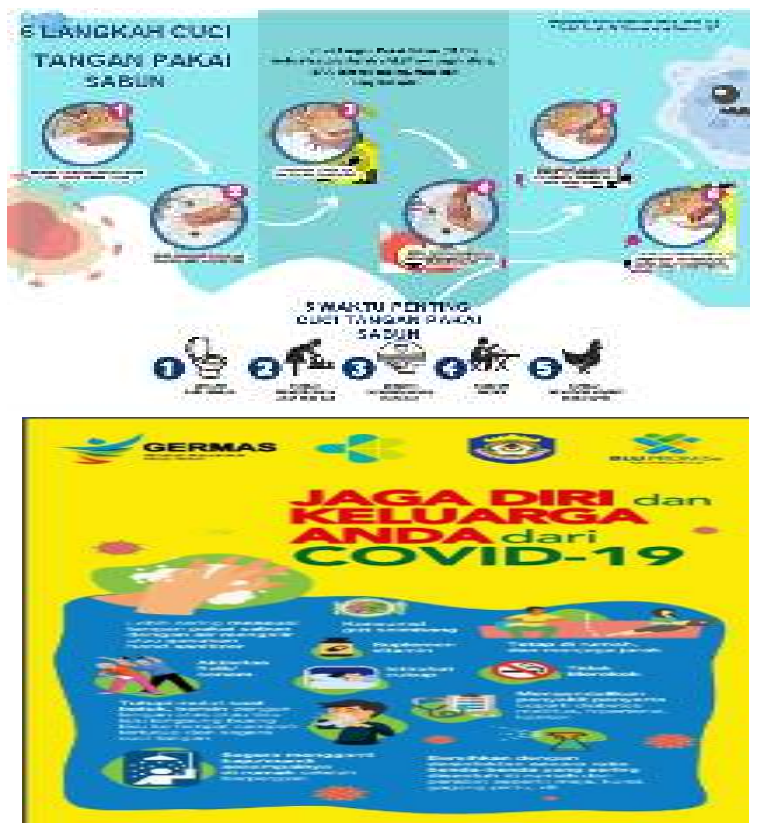

Gambar 2 Foto Media Edukasi Leaflet \& Poster

Hasil penelitian dengan judul Pengaruh Pendidikan Kesehatan dengan Media Leaflet terhadap Pengetahuan Warga dalam Pencegahan Penularan Covid-19 didapat bahwa masyarakat memperoleh pengetahuan 
selain dari media elektronik dan surat kabar juga dari petugas kesehatan dengan menggunakan berbagai metode dan media, salah satunya dengan media leaflet. Alasan memilih leaflet adalah media sederhana tapi menarik dan mudah untuk dibagikan (Jaji, 2020). Tim pengabdian kepada masyarakat juga mendemonstrasikan cara melakukan cuci tangan dan cara menggunakan handsanitizer pada kepala pekon dan petugas.

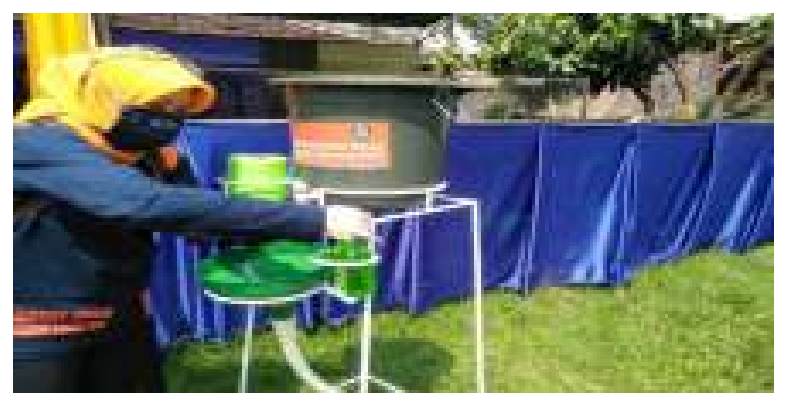

Gambar 3 Praktik Mencuci Tangan

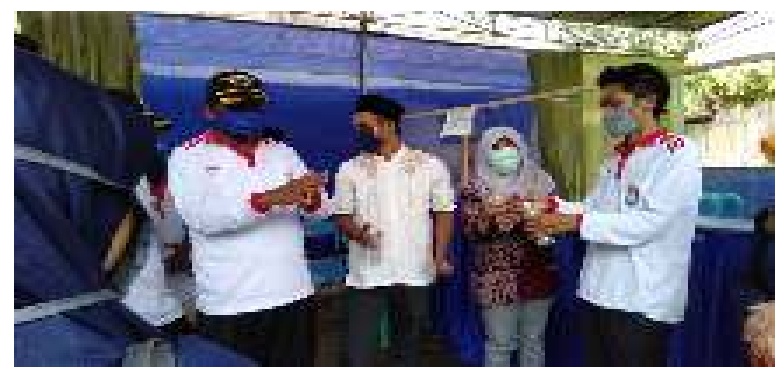

Gambar 4 Praktik menggunakan hand sanitizer

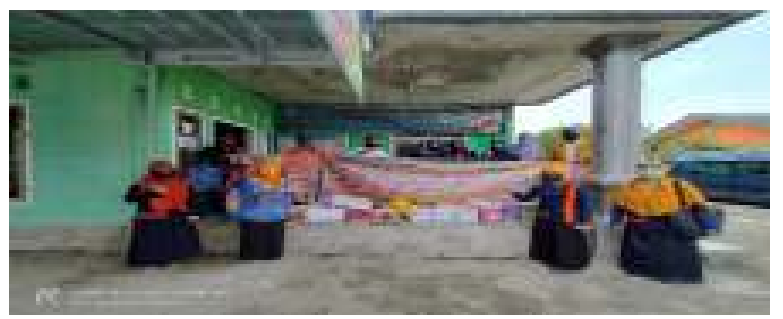

Gambar 5 Distribusi ke Pekon Patoman

Distribusi sarana cuci tangan, masker, handsanitizer dan APD untuk masyarakat diserahterimakan melalui kepala pekon sedangkan Alat Pelindung Diri seperti baju hazmat, masker medis, handscoen, dan hand sanitizer diberikan ke puskesmas. Kelangkaan APD membuat beberapa sarana pelayanan kesehatan membutuhkan donasi APD

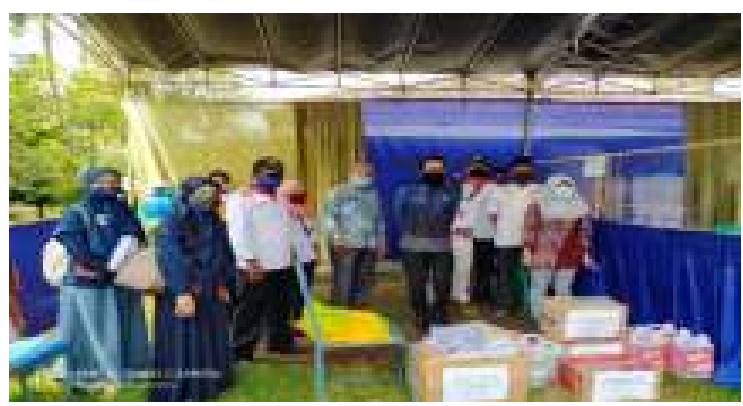

Gambar 6. Distribusi ke Pekon Pagelaran

Hasil pemantauan baik petugas
kesehatan maupun masyarakat telah
memanfaatkan sarana cuci tangan dan alat
pencegahan penularan (masker dan
handsanitizer) yang diberikan, melaksanakan
kegiatan pre test dan post test dan mengisi
survey kepuasan.

\section{Kesimpulan}

Berdasarkan hasil kegiatan pengabdian masyarakat yang telah dilakukan dapat disimpulkan:

a. Peningkatan pengetahuan masyarakat yang ditandai dengan : adanya peningkatan skor post test setelah pemberian media edukasi dan berdasarkan hasil analisis dengan menggunakan uji Wilcoxon.

b. Bantuan masker, handsanitizer, tempat cuci tangan dan sabun terdistribusi ke masyarakat di Pekon Patoman dan Pekon Pagelaran.

c. Bantuan APD terdistribusi ke petugas kesehatan di Puskesmas Pagelaran.

d. Masyarakat memanfaatkan masker, hand sanitizer dan tempat cuci tangan yang dibagikan

e. Hasil survei kepuasan masyarakat terhadap kegiatan yang dilakukan bernilai baik.

\section{Ucapan Terima Kasih}

Ucapan terima kasih terutama ditujukan kepada Camat Pagelaran, Kepala Pekon, Kepala Puskesmas, Kader yang sudah ikut berpartisipasi secara aktif dalam kegiatan pengabdian masyarakat ini baik secara langsung maupun tidak langsung, meskipun kegiatan sudah berakhir, evaluasi pemanfaatan terhadap bantuan yang diberikan dan praktik edukasi masih tetap dilanjutkan oleh kader dan petugas kesehatan. 


\section{Daftar Pustaka}

Fitriani, N. I. (2020). Tinjauan Pustaka Covid-19: Virologi, Patogenesis, dan Manifestasi Klinis. Jurnal Medika Malahayati, 4(3), 194-201. http://ejurnalmalahayati.ac.id/index.php/medika/a rticle/view/3174/pdf

Jaji. (2020). Pengaruh pendidikan kesehatan dengan media leafletterhadap pengetahuan warga dalam pencegahan penularan covid 19. Proceeding Seminar Nasional Keperawatan 2020, 1, 135139.http://conference.unsri.ac.id/index.php/SNK/ article/view/1764

Mujiburrahman, Riyadi, \& Ningsih. (2020). Pengetahuan Berhubungan dengan Peningkatan Perilaku Pencegahan COVID-19 di Masyarakat. Jurnal Keperawatan Terpadu, 2(2), 130-140. http://www.elsevier.com/locate/scp

Syadidurrahmah, F., Muntahaya, F., Islamiyah, S. Z., Fitriani, T. A., \& Nisa, H. (2020). Perilaku Physical Distancing Mahasiswa UIN Syarif Hidayatullah Jakarta pada Masa Pandemi COVID-19. Perilaku Dan Promosi Kesehatan: Indonesian Journal of Health Promotion and Behavior, 2(1), 29. https://doi.org/10.47034/ppk.v2i1.4004 